\title{
The Implementation of Talak Ba'in Sughro towards Apostate Husband
}

\section{Ahmad Nafhani ${ }^{*}$ and Abdullah Arief Cholil ${ }^{* *}$ )}

*) Staff of the Religious Court, students of Master of Law, Faculty of Law Universitas Islam Sultan Agung Semarang, email: ahmadnafhani@gmail.com

**) Faculty of Islamic Religion, Universitas Islam Sultan Agung Semarang

\section{Abstract.}

The purpose of marriage is to form a happy and eternal family based on One Godhead. Marriage can be broken up because one party is Apostate, Apostasy can cause a problem in the household. In this study, the panel of judges decisions in accordance with the laws in Indonesia, namely Act No. 1 of 1974 and Compilation of Islamic Law. The method used by juridical normative focuses on the inventory of positive law, legal principles and doctrines, legal findings in concrete, legal systematics, level of legal synchronization, comparative law. Research findings the Demak Religious Court based on its relative and absolute competence has the right to examine, decide, and settle the case at the first level, so it is appropriate if the Plaintiff registers the case with the Demak Religious Court, for divorce on grounds, religious conversion or apostasy which causes dissonance in the household. That the separation that occurred as a result of the apostasy of one of the husband and wife couples from Islam was a fasakh, not a fall in the divorce of Ba'in Sughro. The purpose of the research itself is to be able to present accurate data so that it can provide benefits and be able to solve problems.

Keywords: Implementation; Divorce; Apostate.

\section{Introduction}

Islam understands and realizes this, therefore Islam opens the possibility of divorce, either by divorce or by divorce in order to uphold the principles of human freedom and independence. Although the purpose of marriage is as Compilation of Islamic Law (KHI) in Article 2 physical and mental bond between a man and a woman as husband and wife with the aim of forming a happy and eternal family or household based on the Supreme Lordship, of course that happiness will not be achieved in things that cannot be adjusted, because happiness cannot be forced. Imposing happiness is not happiness, but suffering. Therefore Islam does not bind marriage to death, but it does not make divorce easier. ${ }^{1}$

According to Article 2 of the Marriage Law, it is stated that a marriage is legal, if it is carried out according to the law of each religion and belief, besides this marriage must be recorded according to the prevailing statutory regulations. In this regard, the implementation of marriage based on religion and belief is an

\footnotetext{
1 Law of the Republic of Indonesia Number 1 of 1974 concerning Marriage and Compilation of Islamic Law, printed VI Bandung: Citra Umbara, 2011.
} 
absolute requirement regarding whether or not a marriage is valid. Regarding the matter of recording done, it does not conflict with the applicable law.

Regarding marriage registration, it is not something that is strictly regulated as a legal condition of marriage but has important consequences for the husband and wife relationship, because it is proof that the marriage actually took place, and also aims to guarantee legal order and certainty as well as proof in the field of marriage. Sometimes a problem arises in a marriage, if the marriage has been going on for several years then one of the parties or both have changed religions, for example from Islam to non-Islam, this results in the marriage being no longer harmonious to disturb the peace and of course a problem will arise. which in the end the marriage ran aground in the middle of the road leading to divorce. $^{2}$

Article 1 paragraph (1) of Act No. 50 of 2009 concerning the second amendment to Act No. 7 of 1989 concerning the Religious Courts states that the Religious Courts are Courts for Muslims. In relation to the content of the article, the position of the Religious Courts is only for Muslims. However, in this case the Religious Courts do not only see the identity side of their side but also see the legal events that occur, if the incident is carried out based on Islamic Law then the settlement must also be based on Islamic Law.

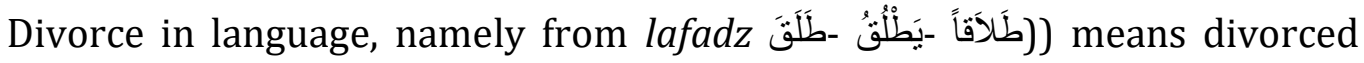
woman from her husband. ${ }^{3}$ Whereas in terms of terms is a divorce imposed by the husband against the wife. ${ }^{4}$ In the Big Indonesian Dictionary explains the meaning of divorce is divorce between husband and wife or the dissolution of the marriage bond. ${ }^{5}$

The issue of breaking up of marriage, Act No. 1 of 1974 regulates it in Chapter VIII Articles 38 to Article 40:6

Article 38: Marriages can be broken up due to (a) death (b) divorce (c) by court decision.

In the compilation, it is also regulated in more detail regarding the causes of divorce in Chapter XVI, Articles 113 to 116, as follows:

Article 113: Marriages can be broken up due to (a) death (b) divorce (c) by court decision.

Article 114: A marriage breakdown caused by divorce can occur because of divorce or based on divorce.

Article 115: Divorce can only be carried out before a religious court hearing after the religious court tried and failed to reconcile the two parties.

\footnotetext{
2 Thalib Al Hamdani, 2002, Risalah Nikah (Hukum Perkawinan Islam), Jakarta: Pustaka Amani, p. 2. ${ }^{3}$ Mahmud Yunus, 1989, Kamus Arab-Indonesia, Jakarta: PT. Hida Karya Agung, p. 239.

${ }^{4}$ Kamal Muchtar, 1974, Asas-asas Hukum Islam tentang Perkawinan, First Printing Jakarta: Bulan Bintang, p. 144.

5Dendi Sugono, 2008, Kamus Besar Bahasa Indonesia Pusat Bahasa, First Printing, 4th Edition, Jakarta: PT. Gramedia Pustaka Utama, p. 94

${ }^{6}$ Ahmad Rofiq, 2003, Hukum Perdata Islam di Indonesia, Revised Edition, First Printing, Jakarta: Raja Grafindo Persada, p. 217.
} 
Article 116:Divorce can occur for the following reasons or reasons:

a. One of the parties commits adultery or becomes a drunkard, a prostitute, a gambler and others who are difficult to cure;

b. One of the parties leaves the other party for 2 (two) consecutive years without the permission of the other party and without valid reasons or for other reasons beyond his means;

c. One of the parties is sentenced to 5 (five) years imprisonment or a heavier sentence after the marriage takes place;

d. One party commits cruelty or serious maltreatment that endangers the other party;

e. One of the parties has a disability or illness resulting in not being able to carry out his obligations as husband or wife;

f. Between husband and wife there are constant quarrels and fights and there is no hope of living in harmony again in the household;

g. Husband violates taklik divorce;

h. Religious conversion or apostasy which causes disharmony in the household. 7

In connection with this issue in the decision at the Demak Religious Court in 2017, it explained that during the marriage of the Plaintiff and Defendant there had never been a divorce, then after that the domestic order of the Plaintiff and Defendant began to waver, there were frequent disputes and fights, due to differences in principle in terms of religion, the Defendant returned to his original religion, namely Christianity. Even though the Plaintiff had tried to guide the Defendant to remain in Islam, the Defendant continued to believe in the Defendant by embracing Christianity (apostasy).

Riddah (murtad/apostate) is a return to the original path, what is desired by riddah is the return of a wise and mature Muslim to infidelity on his own accord without coercion from others. Whether it was a boy or a girl who returned. ${ }^{8}$

Separation of husband and wife due to fasakh is different from divorce, because talak is talak raj'i and talak Ba'in, talak raj'i does not end the marriage immediately and talak ba'in ends the marriage immediately. In addition, the separation of husband and wife because talak can reduce the number of talak. As for fasakh, either because of unfulfilled conditions or because of things that happened later, he ended the marriage bond immediately, but the separation of husband and wife because fasakh did not reduce the divorce number. ${ }^{9}$

The purpose of the study itself is to provide a perspective on solving cases of divorce problems, especially in the issue of apostasy of a person in the marriage bond in law and as well as legal review of fiqh while still paying attention to the legality of divorce as happened in the judicial process at the Demak Religious Court in 2017.

\footnotetext{
7 Ibid., p. 268-269.

8Sayyid Sabiq, 1990, Fikih Sunnah, Volume 9, 5th Printing, translated by Moh. Nabhan Husein, Bandung: PT Alma'arif, p. 159.

${ }^{9}$ Sayyid Sabiq, 1980, Fikih Sunnah, volume 8, $1^{\text {st }}$ Printing translated by Moh. Thalib, Bandung: Al Ma'arif, p. 125.
} 


\section{Research Methods}

This research, using the juridical normative method, focuses on the inventory of positive law, legal principles and doctrines, legal findings in concrete, legal systematics, legal synchronization levels, comparative law and legal history. While the approach taken to answer the problems of this research is the statutory approach. ${ }^{10}$ The specification in this research is descriptive analysis, because it is related to divorce regarding the divorce of one Ba'in Sugroto an apostate husband which is associated with the implementation of positive law concerning the problems under study.

Sources of data used in this study include: Primary data is the words and actions of the people being observed or interviewed. While the secondary data of this research was conducted using field research methods. Data collected directly from the source at the research site. In primary data collection, the author uses several techniques to obtain data by observation and interviews. ${ }^{11}$ The data obtained in this study were analyzed qualitatively, that is, the data obtained were then systematically compiled for further analysis to achieve clarity regarding divorce by making a decision regarding the divorce of one Ba'in Sugroto an apostate husband.

\section{Results And Discussion}

3.1. Concept the decision of the Demak Religious Court Number 2002 / Pdt. G / 2017 / PA. Dmk. about Talak Ba'in Sugro given to an apostate husband can be a reason for divorce according to Act no.1 of 1974 and the Compilation of Islamic Law

Divorce is the breaking of a husband and wife relationship in a legal marriage bond. Divorce can also be interpreted as breaking a sacred promise that has been mutually agreed upon when pronouncing the consent qobul. Even for most people, divorce also breaks the relationship between the families of both parties. So it is not wrong if divorce is the thing most hated by Allah SWT.

In the formulation of reasons that can be used by a person to divorce, this is as regulated in the Elucidation of Article 39 paragraph (2) of Act No. 1 of 1974 in conjunction with Article 116 Compilation of Islamic Law, namely:

a. One of the parties commits adultery or becomes a drunkard, a prostitute, a gambler, and others who are difficult to cure;

b. One of the parties leaves the other party for 2 (two) consecutive years without the permission of the other party and without valid reasons or for reasons beyond its capabilities;

c. One of the parties is sentenced to 5 (five) years imprisonment or a heavier sentence after the marriage takes place;

${ }^{10}$ Muhammad Abdul kadir, 2007, Hukum dan Penelitian Hukum, Bandung: PT. Citra Aditya Bakti, p. 52

${ }^{11}$ Moleong lexy, 1999, Metodologi Penelitian, Bandung: PT.Remaja Rosada Karya, p. 114 - 157 
d. One party commits cruelty or serious maltreatment that endangers the other party;

e. One of the parties has a disability or illness resulting in not being able to carry out his obligations as husband or wife;

f. Between husband and wife there are constant quarrels and fights and there is no hope of living in harmony in the household.

g. Husband violates his divorce taklik;

h. Religious conversion (apostasy) which causes disharmony in the household.

In the case of Number 2002 / Pdt. G / 2017 / PA.Dmk.The Religious Courts have examined and adjudicated civil cases in the first instance and have made decisions in cases of petition for divorce filed by the wife as the plaintiff and her husband as the defendant. This case could be heard at the Demak Religious Court because both parties were legally married on June 3, 1987 according to the Duplicate Quote of Marriage Deed number 57 / Kua.11.27.09 / PW.01 / 10/2017, dated 30 October 2017.

The Plaintiff resides in Demak Regency so based on the relative competence of the Plaintiff it is appropriate to register his case at the Demak Religious Court, because it is the Plaintiff's jurisdiction. Apart from that, the Demak Religious Court also has the right to settle the case, because based on the provisions on relative authority it is generally regulated in Article 118 HIR / 142 Rbg, and is specifically regulated in legislation. In principle, the lawsuit is submitted to the Religious Court at the residence of the Plaintiff / Respondent (wife) by an interested party and has legal ties, while the petition is submitted to the Religious Court where the plaintiff resides unless the law stipulates otherwise. ${ }^{12}$

The marriage between the Plaintiff and the Defendant was carried out based on Islamic law, so that the Plaintiff's petition was appropriate because he submitted his application to the Demak Religious Court not to another court. Based on absolute competence in the field of marriage, the Demak Religious Court has the right to examine, decide, and settle cases Number 2002 / Pdt. G / 2017 / PA. Dmk.

In Article 49 to Article 53 of Act no. 3 of 2006 describes the authority and power to judge which is the burden of the duties of the Religious Courts. Article 49 stipulates that the Religious Courts have the duty and authority to examine, decide, and resolve cases at the first level between people who are Muslim in the fields of marriage, inheritance, wills, grants, waqf, zakat, infaq, shadaqah and economics sharia. ${ }^{13}$ So, the relative and absolute authority of the Demak Religious Court is in accordance with the applicable regulations. In a copy of the Decision of the Demak Religious Court, it is contained as follows:

a. Principal; The first structure in this section is the decision followed below it by the decision number taken from the case number, followed by the sentence

\footnotetext{
${ }^{12}$ Mukti Arto, 2003, Praktek Perkara Perdata pada Pengadilan Agama, Yogyakarta: Pustaka Pelajar, p. 45.

${ }^{13}$ Compilation of Laws and Regulations on the Indonesian Marriage Law, Complete Edition, Jakarta: Intellectual Discourse, Cet. 1, 2009, p. 435.
} 
"BISMILLAHIRRAHMANIRRAHIM" followed by the sentence "FOR JUSTICE BASED ON THE ALMIGHTY GOD".

b. Identity of the Parties; The identity of the parties must be clearly written in the decision, namely: name, age, address, occupation, place of residence, and position as party, as well as their proxies if the person concerned is empowered by another person.

c. Sit Case; Every court decision in a civil case must contain a brief summary of the Respondent's petition or response in a concise and clear manner, in addition, the decision letter must also clearly state the basic reasons for the decision, articles of the applicable laws and regulations, the decision, the chairman of the assembly, members of the assembly and replacement committee members, the cost of the case, as well as the presence and absence of the litigants at the time the verdict was pronounced.

d. About Legal Considerations; In this legal consideration, the judge must consider the arguments of the lawsuit, rebuttal or exception of the Defendant and its connection with existing evidence. From legal considerations, the judge drew conclusions about whether or not the petition for divorce was proven.

e. About Decision; In that injunction the judge must state what matters are granted, rejected, or not accepted based on the legal considerations he has done.

f. Closing Part; In this section it states when the decision was decided (day and date) and also includes the name of the Chief Judge and Member Judge examining the case according to the decision of the Panel of Judges appointed by the head of the Religious Court..

From the data above, it can be concluded that the Demak Religious Court based on its relative and absolute competence has the right to examine, decide, and settle the case at the first level, because the Plaintiff's domicile is still in Demak district, whose territory is the duty and authority of the Demak Religious Court. Marriage of the Lawyer and Defendant is carried out based on Islamic law, so it is appropriate for the Petitioner to register the case at the Demak Religious Court. Therefore, if viewed from the procedural law (formal law), the Demak Religious Court in deciding case Number 2002 / Pdt. G / 2017 / PA. Dmk. Regarding the divorce of Ba'in Sughro to an apostate husband, it has been appropriate since the procedure for filing a case until the case is decided.

\subsection{The Basis for Legal Considerations of the Demak Religious Court Judge in Deciding on Divorce Case About Ba'in Sugro's One-Stop Divorce to Apostate Husband}

In the decision of the Demak Religious Court judge Number 2002 / Pdt. G / 2017 / PA.Dmk regarding the divorce of one Ba'in Sugro to the apostate husband, based on witnesses and evidence shows that the Defendant has clearly returned to his original religion, namely Christianity. And according to Islamic law, the Defendant can already be said to be an apostate because it has met the conditions 
for a person to be said to be an apostate as explained above, namely being sensible and of his own will.

Chairman of the Panel of Judges in decision Number 2002 / Pdt. G / 2017 / PA.Dmk. explained that in the case it was decided to divorce one Ba'in Sugro, because the filing of the case was filed by the Plaintiff and the fall of talak ba'da dukhul (after gathering) with evidence that the Plaintiff and Defendant had been blessed with 4 children and the divorce was the first time. ${ }^{14}$

Imam Shafi $i$ explained, not all the breaking of the marriage bond is called talaq, if one of the husband and wife is apostate, or one of them converts to Islam while the other remains in disbelief until the end of the iddah period, then it is called fasakh, there is no occurrence of divorce in him.

Meanwhile, Allah forbids unbelievers to mix with Muslim women and forbids believers to mix with infidel women other than the people of the book. ${ }^{15}$

In the book Al-Fiqhu Al-Islam wa 'Adillatu according to the Maliki School, that separation in marriage includes divorce if:

a. First, using the word talaq in a marriage that is valid or the damage is disputed.

b. Second, there was separation from the khulu in a legal marriage or where the damage was disputed.

c. Third, the separation that occurs as a result of 'il' is that the husband swears he will not approach his wife for more than four months. If he does not break his vow after Qadhi ordered him to cancel it after his wife's complaint, then the two are separated, and this separation is divorce.

d. Fourth, separation that occurs due to the absence of equality on the part of the husband, whether this separation arises from the wife or from the wife's guardian.

e. Fifth, separation that occurs due to lack of income or ill treatment.

f. Sixth, separation that occurs due to apostasy of one husband and wife from Islam. This separation is divorce according to the famous school of thought, because it is a separation due to a sudden incident which obliges an immortal prohibition, which ends with his return to Islam. ${ }^{16}$

The two opinions above are clearly different, it can be described that according to Imam Shafi $i$ if one of the husband and wife apostatizes or one of them converts to Islam while the other remains in disbelief until the end of iddah, then it is called fasakh. Meanwhile, according to the Maliki School in the sixth point, the separation that occurs as a result of the apostasy of a husband and wife from Islam, this separation is divorce according to the famous school of thought because this is

\footnotetext{
${ }^{14}$ Interview with the Chief Judge Council 0 in the Decision of the Demak Religious Court Number 2055 / Pdt. G / 2012 / PA. Demak. Thursday, 25 September 2014.

${ }^{15}$ Imam Shafi i Abu Abdullah Muhammad bin Idris, Mukhtashar Kitab Al Umm fi Al Fiqh, translated by Imron Rosadi and Imam Awaluddin, 2009, Ringkasan Kitab Al Umm, Jakarta: Pustaka Azzam, p. 534.

16Wahbah Al-Zuhali, Al-Fiqhu Al-Islam wa 'Adillatu, Volume 9, translated by' Abdu Al-Hayyi AlKattani, Jakarta: Gema Insani, 2011, p. 314
} 
a separation due to a sudden incident which obliges an immortal prohibition, which ends with his return from Islam.

The majority of the population of Indonesia adheres to the Shafi $i$ school of thought, but also does not deny other schools which are categorized as the AlArba'ah School, and schools other than Shafi when the law has become an agreement and codified, then the law must also be obeyed. ${ }^{17}$

The above explains that, the decision of the Demak Religious Court Judges Number 2002 / Pdt. G / 2017 / PA.Dmk. regarding the divorce of one Ba'in Sugro to an apostate husband is in accordance with the analysis of Islamic law, because the decision is in line with the KHI Article 116 letter (f) as the opinion of the famous School in point six which states that in the case, divorce is punished, because this separation occurs as a result of apostasy of one husband and wife from Islam and because of this it is a separation as a result of a sudden incident which obliges a prohibition which is not eternal, which ends with his return from Islam, while talak in this decision is categorized as divorce of one Ba'in Sugro because of the fall of talak ba'da dukhul (after gathering) and it's the first time.

Overall, the decision of the Demak Religious Court Judges Number 2002 / Pdt. G / 2017 / PA.Dmk. Regarding the divorce of one Ba'in Sugro to a husband who is legally positive apostasy, the verdict is in accordance with the provisions in Article 39 paragraph 2 of Act No. 1 of 1974 jo. Article 19 letter f Government Regulation Number 9 of 1975 and Article 116 letter $f$ and the Compilation of Islamic Law which reads: (f) Between husband and wife continually disputes and quarrels, which should be the panel of judges in deciding divorce cases regarding Ba'in Sugro divorce to husbands those who murtad associate it with the Compilation of Islamic Law based on article 116 letter (h), namely religious conversion or apostasy which causes harmony in the household, and according to Islamic law the case is punished with talak,

As explained in Islamic law contained in the Book of Al Asybah wan Nadhoir, page 62 , which reads as follows:

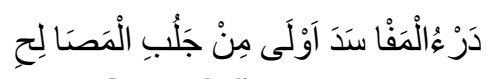

Meaning: "Refusing damage takes precedence over getting benefit"

So, as according to the perspective of the Maqashid Sharia in looking at the suicidal divorce case. Concerning the divorce of Ba'in Sugro to apostate husbands, it is in accordance with Islamic law with the perspective of Maqashid Sharia that prioritizes benefit As seen from the author's point of view, because this separation occurred as a result of the apostasy of one of the husband and wife partners from Islam and because this was a separation as a result of a sudden incident which obliged an immutable prohibition, which ended with his return from Islam, and also to avoid further bad thing especially in the lineage of a child.

\section{Closing}

${ }^{17}$ Sayyid Sabbiq, Fiqh Al-Sunnah, Volume 2, Beirut: Dar Al-Fath, t.th., p. 373-374 
Whereas in the concept of a Demak Religious Court Decision Number 2002 / Pdt. G / 2017 / PA. Dmk concerning the divorce of one Ba'in Sugroagainst an apostate husband who can be the reason for divorce according to Act no.1 of 1974 and the Compilation of Islamic Law, the Demak Religious Court based on its relative and absolute competence has the right to examine, decide, and settle the case at the first level, because the Plaintiff's domicile is still domiciled in Demak Regency, which area is the duty and authority of the Demak Religious Court. The marriage of the Plaintiff and Defendant was carried out based on Islamic law, so it was appropriate for the Plaintiff to register the case at the Demak Religious Court.

To do a divorce, there must be sufficient reasons, that the husband and wife will not be able to live in harmony as husband and wife. jo. Article 19 letter $\mathrm{f}$ Government Regulation No.9 of 1975 and 116 letter f Compilation of Islamic Law, namely: (f) that between husbands and wives continually disputes and quarrels and there is no hope of living in harmony again in the household. And the panel of judges should in deciding divorce cases regarding divorce Ba'in Sugro to apostate husbands related to the Islamic Law Compilation based on article 116 letter (h), namely religious conversion or apostasy which causes harmony in the household. that the separation that occurs as a result of the apostasy of one husband and wife from Islam is divorce, because this separation is a separation due to a sudden incident which obliges a non-eternal prohibition which ends with his return from Islam. While talak in this decision is categorized as talak Ba'in Sugro because as in the lawsuit filed by the Plaintiff uses Article 116 letter $f$ of the Compilation of Islamic Law.

\section{Bibliography}

Al - Zuhali, Wahbah, 2011, Al-Fiqhu Al-Islam wa `Adillatu, volume 9, translated by Abdu Al-Hayyie Al-Kattani, Jakarta: Gema Insani.

Amirudin and Zainal Asikin, 2006, Penghantar Metode Penelitian Hukum, First Printing, Jakarta: Raja Grafindo Persada

Arto, A. Mukti, 1996, Praktek Perkara Perdata Pada Pengadilan Agama, First Printing, Yogyakarta: Pustaka Pelajar

Al Hamdani, Thalib, 2002, Risalah Nikah (Hukum Perkawinan Islam), Jakarta: Pustaka Amani.

Compilation of Laws and Regulations - Invitation, Indonesian Marriage Law Complete Edition, Intellectual Discourse, Cet. 1, 2009.

Law of the Republic of Indonesia Number 1 of 1974 concerning Marriage and Compilation of Islamic Law, Prints VI Bandung: Citra Umbara, 2011.

Mahmud, Yunus, 1964, Hukum Perkawinan Dalam Islam, Jakarta: CV. Al Hidayah.

Muchtar, Kamal, 1974, Asas - asas Hukum Islam tentang Perkawinan, First Printing, Jakarta: Bulan Bintang 
Muhammad, Imam Shafi i Abu Abdullah bin Idris, 2009, Al Umm, translated by Imron Rosadi and Imam Awaluddin, Ringkasan Kitab Al Umm, Jakarta: Pustaka Azzam.

Rofiq, Ahmad, 2003, Hukum Perdata Islam di Indonesia, First Printing, Revised Edition, Jakarta: Raja Grafindo Persada

Sabiq, Sayyid, 1980, Fikih Sunnah, volume 8, First Printing, translated by Moh. Thalib, Bandung: Al Ma'arif

---------, 1990, Fikih Sunnah, Jilid 9, 5th Printing, translated by Moh. Nabhan Husein, Bandung: PT Alma'arif

----, 1990, Fiqh Al-Sunnah, Volume 2, Beirut: Dar Al-Fath.

Sugono, Dendi, 2008, Kamus Besar Bahasa Indonesia Pusat Bahasa, First printing, issue 4, Jakarta: PT. Gramedia Pustaka Utama

Interview with the Chief Judge in the Decision of the Demak Religious Court Number 2055 / Pdt. G / 2012 / PA. Demak. Thursday, 25 September 2014.

Kadir, Muhammad, Abdul, 2007, Hukum dan Penelitian Hukum, Bandung: PT. Citra Aditya Bakti.

Lexy, Moleong, 1999, Metodologi Penelitian, Bandung: PT. Remaja Rosada Karya. 